\title{
ANALISIS BIBLIKA TENTANG "KOTA-KOTA PERLINDUNGAN" BERDASARKAN ULANGAN 19:1-13 DAN RELEVANSINYA BAGI GEREJA MASA KINI
}

\author{
Yosua Feliciano Camerling \\ Sekolah Tinggi Filsafat Theologia Jaffray Makassar \\ Jalan Gunung Merapi Nomor 103, Makassar, Sulawesi Selatan \\ Email:yosuacamerling@gmail.com
}

\begin{abstract}
ABSTRAK: Dalam tulisan ini, peneliti melakukan analisis biblika dari teks Ulangan 19:113. Teks ini kelihatannya tidak mudah dimaknai ke dalam situasi di zaman modern. Maka dari itu, dengan melakukan tafsiran terhadap teks tersebut, menolong pembaca untuk melihat makna teologis yang relevan atau masih bisa diterapkan ke dalam kehidupan masa kini. Teks Ulangan 19 berbicara tentang kota-kota perlindungan yang tampaknya masih ada kemiripan kasus dengan hukum pidana di Indonesia seperti contohnya tahanan kota dan rumah tahanan negara. Adapun metode yang digunakan dalam penelitian ini adalah metode kualitatif dengan menggunakan pendekatan deskriptif analisis teks Ulangan 19:1-13. Berdasarkan hasil penelitian ini terlihat bahwa Allah adalah Allah yang Maha Berdaulat, Allah yang Maha Pemurah dan Allah yang Maha Adil. Untuk itu orang percaya dituntut untuk setia melakukan perintah Allah, percaya bahwa Yesuslah pelunas hutang darah yang sejati dan orang percaya juga perlu hidup dalam kekudusan.
\end{abstract}

Kata Kunci: relevansi kota-kota perlindungan, tahanan kota, rutan, Ulangan 19:1-13, taurat

\section{ANALYSIS ON "THE CITIES OF REFUGE" BASED ON DEUTERONOMY 19:1-13 AND ITS RELEVANCY FOR THE CURRENT CHURCH}

\begin{abstract}
In this paper, the researcher conducted a biblical analysis of Deuteronomy 19: 1-13. This text does not seem to be easily interpreted in the situation of modern times. Therefore, by interpreting the text, it helps the reader to see the theological meaning which is relevant or can still be applied in the present life. The text of Deuteronomy 19 talks about cities of refuge that appear to have similarities to cases of criminal law in Indonesia, such as city prisoner and detention centers. The method used in this paper is a qualitative method using the textual approach to Deuteronomy 19:1-13. Based on the results of this study, it can be seen that God is a Sovereign God, a Merciful God, and a Just God. For this reason, believers are required to carry out God's commands faithfully, believe that Jesus is the true payer of the blood debt, and believers also need to live in holiness.
\end{abstract}

Keywords: the relevance of cities of refuge, city prisoner, detention centers, Deuteronomy 19: 1-13, torah 


\section{PENDAHULUAN}

Alkitab merupakan firman Allah yang hidup dan karena itu selalu relevan untuk diterapkan di setiap zaman. Bahkan Alkitab berotoritas dan berperan penting dalam seluruh aspek kehidupan manusia (2 Tim. 3:16-17) (Lewis, 2014, p. 329). Namun ada beberapa orang percaya yang agaknya bingung dalam memahami dan menafsirkan Alkitab secara khusus Perjanjian Lama. Salah satu tantangan yang cukup kompleks dalam mempelajari Perjanjian Lama yakni bagaimana setiap teolog dapat menafsirkan Perjanjian Lama sesuai dengan statusnya sebagai firman Allah, yang terus bisa diterapkan dalam kehidupan jemaat masa kini (Brake, 2019, p. 2).

Salah satu kitab dalam Perjanjian Lama yang agaknya sulit untuk diterapkan pada zaman kini ialah kitab Pentateukh. Dalam penelitian yang dilakukan oleh Preston L. Mayes, ia menjabarkan bahwa banyak peraturan yang terkandung dalam kitab Pentateukh tampaknya asing bagi pembaca modern, baik itu tentang imamat, sistem pengorbanan dan hari libur keagamaan tidak dipraktikkan atau diparalelkan dalam kehidupan bergereja masa kini. Bahkan meskipun memiliki pengajaran dan nilai ilustratif sebagai jenis pekerjaan Kristus, orang percaya sering bergegas untuk melewatkan sama sekali kitab ini dalam pelajaran Alkitab pribadi mereka (Mayes, 1998, p. 1).

Salah satu dari Kitab Pentateukh yang tampaknya rumit untuk dipahami oleh orang Kristen adalah Kitab Ulangan. Paul Barker mengatakan,

Orang Kristen jelas menghadapi beberapa masalah dalam menafsirkan Kitab Ulangan dan menerapkannya pada masa kini. Kitab Ulangan meminta penduduk Kanaan dihabisi tanpa ampun. Banyak orang Kristen akan menolak peperangan dan perilaku keji demikian, dan itu benar. Tetapi bukannya menganggap seluruh kitab ini telah usang dan tak lagi relevan, kita menemukan bahwa prinsip-prinsip dasarnya penting (Barker, 2014, p. 21-22).

Teks ini agaknya sulit dipahami bagi banyak orang. Barnabas Ludji pun mengatakan demikian bahwa teks-teks ini kelihatannya tidak mudah dimaknai ke dalam situasi dan zaman modern. Dengan melakukan tafsiran terhadap teks-teks ini, menolong pembaca untuk melihat makna teologis dari teks-teks tersebut yang relevan atau masih bisa diterapkan ke dalam kehidupan masa kini. Teks Ulangan 19 berbicara tentang kota-kota perlindungan yang tentu saja tidak dikenal di zaman modern ini. Pasal ini menyajikan tafsiran Ulangan 19:1-13 yang dibandingkan dengan teks-teks sejajar, yaitu Bilangan 35:9-34 dan Yosua 20:1-9 (Ludji, 2009, p. 63).

Selain itu, masalah lain muncul dalam penelitian yang dilakukan oleh Kevin Mattison, di mana ia berargumen bahwa undang-undang Ulangan dan Bilangan yang memberikan suaka kepada pembunuh yang tidak disengaja (UI. 19:1-13; Bil. 35:9-34) sangat berbeda dalam prosedur dan tujuan mereka. Perbedaan antara hukum-hukum ini mencerminkan konsepsi dasar yang berbeda dari pertumpahan darah (Mattison, 2018, p. 232). Pandangan ini juga senada dengan penelitian yang diadakan oleh Eliezer Hadad. la mengutarakan pendapatnya bahwa perikop kota-kota perlindungan muncul di Pentateukh di dua tempat: dalam Bilangan 35 dan Ulangan 19. Artikel ini menunjukkan bahwa perbedaan antara perikop ini muncul dari logika internal yang berbeda dari setiap teks (Hadad, 2017, p. 155). Bahkan Jeffrey Stackert menyatakan bahwa ketidaksepakatan ini berlanjut tentang hubungan legislasi ini dengan narasi implementasinya dalam Yosua 20:1-9 (Stackert, 2006, p. 23). Inilah beberapa masalah teks yang peneliti temui tentang "kota-kota perlindungan."

Dalam penelitian ini, peneliti akan berfokus kepada teks Ulangan 19:1-13 yang menggambarkan bahwa dalam suatu negeri 
terdapat tiga kota yang perlu dikhususkan seluruh lokasinya sebagai kota-kota perlindungan. Sebab dalam teks ini ada beberapa hal yang relevan untuk diterapkan pada masa kini, di antaranya yaitu peneliti akan sedikit menyinggung mengenai masalah kemiripan kasus ini dengan hukum pidana di Indonesia seperti contohnya tahanan kota yang diatur dalam KUHAP dan rumah tahanan negara (rutan) yang diatur oleh peraturan pemerintah sehingga teks Ulangan 19:1-13 ini dapat direlevansikan bagi gereja masa kini.

\section{METODE PENELITIAN}

Metode yang digunakan dalam penelitian ini adalah metode kualitatif. Metode penelitian ini mengembangkan kemampuan peneliti ketika mendalami suatu kejadian. Metode ini juga sesuai dengan kondisi di mana peneliti hendak berfokus pada suatu kejadian tertentu dari perspektif yang lebih luas dan menyeluruh (Drew, Hardman \& Hosp, 2017, p. 262-263).

Adapun teks yang ingin peneliti analisa lebih dalam adalah Ulangan 19:1-13 di mana peneliti menggunakan pendekatan deskripsi analisis yaitu awalnya dengan mencari kata asli dari beberapa teks penting kemudian diteliti akar katanya dan kemudian peneliti melihat dan mengutip pandangan beberapa pakar biblika dan teolog. Setelah itu pengambilan kesimpulan dari semua hasil pembahasan tersebut untuk merumuskan suatu pokok penting mengenai "kotakota perlindungan" dalam teks Ulangan 19:1-13.

Tujuan dari penelitian ini adalah untuk menganalisis secara biblis dan teologis maksud dari penulis Kitab Ulangan dalam menyampaikan hukum ilahi yang berasal dari Tuhan Allah kemudian direlevansikan bagi kehidupan bergereja pada masa kini. Sebab mengutip perkataan dari Richard L. Pratt, Jr.,

Alkitab mengungkapkan kebenaran ilahi yang kekal dan universal sehingga se- nantiasa relevan untuk menjawab permasalahan hidup manusia di setiap zaman. Namun karena Alkitab ditulis dalam konteks budaya dan bahasa manusia pada masa tertentu yang jauh dari kita, maka dibutuhkan usaha yang sungguhsungguh dari kita yang hidup pada masa kini untuk memahami makna yang hendak Allah sampaikan kepada kita (Pratt, Jr., 2005, p. xiii).

Untuk memudahkan penelitian ini, peneliti mengumpulkan beberapa sumber penelitian melalui studi kepustakaan (library research) yang mana studi ini berfokus pada teks Alkitab yang menjadi sumber utama dan buku-buku serta beberapa jurnal dari internet sebagai sumber penunjangnya. Berkaitan dengan pengumpulan beberapa sumber penelitian, peneliti lebih berfokus terhadap karya-karya dari beberapa pakar yang membidangi tafsir Perjanjian Lama seperti Peter C. Craigie, Victor P. Hamilton, A. D. H. Mayes dan R. E. Harlow untuk mendapatkan kesimpulan dari analisis teks Ulangan 19:1-13.

Adapun analisis teks Ulangan 19:1-13 dilakukan dengan pendekatan deskriptif berupa eksposisi teks. Eksposisi lebih memperhatikan aplikasi dan hubungan Alkitab tersebut dengan diri penafsir (Sutanto, 2007, p. 10). Setelah itu peneliti kemudian melanjutkan penelitian ini dengan menganalisis teks Ulangan 19:1-13 tentang "kota-kota perlindugan" dan mencari relevansinya bagi gereja masa kini.

\section{HASIL DAN PEMBAHASAN}

\section{Analisis Ulangan 19:1-13}

Seperti yang sudah disampaikan dalam pendahuluan bahwa Ulangan 19:1-13 berbicara tentang "kota-kota perlindungan" sejajar dengan teks Bilangan 35:9-34 dan Yosua 20:1-9. Victor P. Hamilton menjelaskan mengenai pasal ini dalam tulisannya. la mengungkapkan bahwa ayat 1-13 berisi pengaturan mengenai enam kota perlin- 
dungan. Fenomena ini telah dijelaskan secara singkat dalam Keluaran 21:12-14 dan lebih panjang dalam Bilangan 35:9-34. Kota-kota ini memberikan suaka atau perlindungan bagi pembunuh yang melakukan pembunuhan tanpa sengaja (manslayer) tetapi tidak untuk pembunuh yang sudah merencanakan aksi pembunuhannya (murderer) (Hamilton, 1982, p. 433).

$\mathrm{Hal}$ tersebut sejajar dengan pandangan The Wycliffe Bible Commentary yang menjelaskan bahwa:

Tema keadilan hukum dilanjutkan dengan serangkaian peraturan yang diarahkan untuk memastikan terjadinya proses pengadilan serta pengambilan keputusan yang adil. Perlindungan disediakan bagi seorang pembunuh terhadap murka seorang pembalas dendam hingga dapat diproses secara hukum dengan adil (ay. 113). Mengutak-atik bukti sehingga menguntungkan salah satu pihak tidak diperbolehkan (ay. 15-21). Peraturanperaturan ini dimaksudkan untuk menyediakan keadilan dengan melindungi orang yang tidak bersalah, sekalipun keadilan juga harus dipenuhi dengan hukuman yang setimpal terhadap orang yang bersalah (ay. 11-13, 19-21) (Pfeiffer \& Harrison, 2004, p. 498).

Artinya dapat diketahui bahwa kota ini dimaksudkan Tuhan untuk melindungi seorang pembunuh terhadap murka seorang pembalas dendam sehingga terjadi suatu keadilan, sekalipun setiap kesalahan atau dosa harus ada konsekuensinya. Selanjutnya lebih jelas dapat dilihat dari pandangan Peter Craigie mengenai kota-kota ini. la berpendapat bahwa "kota-kota perlindungan" pada awalnya sudah disebut secara singkat di Ulangan 4:41-43; di bagian itu, tiga kota yang disebutkan namanya dan diatur untuk melayani sebagai kota perlindungan bagi suku-suku yang berada di sebelah timur lembah Yordan. Dalam ayatayat ini, tidak ada kota yang disebutkan namanya, untuk bangsa Israel sebelum menyeberangi sungai Yordan dan di bawah kepemilikan tanah yang dijanjikan kepada mereka oleh Tuhan (ay. 1). Ayat-ayat ini menjelaskan kedua prosedur untuk menunjuk kota-kota dan fungsi mereka dalam kaitannya dengan hukum pidana Israel. Lembaga kota-kota perlindungan tampaknya menjadi perluasan hukum sederhana yang terkandung dalam Keluaran 21:12-14, di mana altar (mungkin di tempat kudus Tuhan) yang ditawarkan sebagai perlindungan kepada pembunuh (manslayer), tetapi tidak untuk pembunuh berencana (murderer). Sebagai orang Israel yang menguasai tanah, bagaimanapun juga, tempat kudus dan mezbah jaraknya cukup jauh dari mayoritas penduduk. Kota-kota yang strategis di seluruh wilayah Israel, akan melengkapi fungsi tertentu dari tempat kudus dan mezbah tersebut (Craigie, 1976, p. 265).

Maka dari itu, dapat diketahui bahwa Allahlah yang merancang keadilan bagi setiap bangsa Israel agar tidak ada lagi orang-orang yang berlaku tidak adil terhadap sesamanya. Namun bukan berarti di kota ini seorang penjahat lepas dari tanggung jawabnya melainkan dapat diberikan hukuman yang setimpal dengan tindakan yang ia lakukan. Bukannya malah lebih berat diakibatkan murka dari orang yang membalaskan dendamnya tersebut.

Ludji memberikan pemahamannya bahwa ayat 1 merupakan penjelasan mengenai dasar ataupun jiwa dari penetapan kota-kota perlindungan. Alasannya ialah perbuatan besar Allah bagi umat-Nya berupa pemberian tanah perjanjian kepada umat. Orang Israel menduduki tanah perjanjian semata-mata adalah anugerah/pemberian Allah kepada umat karena kasih-Nya. Sebab itu, kasih dan anugerah Allah itu juga harus nyata dalam seluruh aspek kehidupan umat, termasuk di dalamnya hal penegakkan keadilan. Keputusan peradilan yang berdasarkan kasih dan anugerah Allah adalah keputusan yang 
paling adil. Sebab sebuah keputusan peradilan tidak boleh didasarkan pada kebencian, hati yang panas atau kemarahan yang meluap-luap. Keputusan yang diambil dalam situasi seperti itu akan rawan subjektivitas yang tinggi, sehingga terdakwa menjadi korban ketidakadilan. Karena itu, dasar yang disebut dalam ayat 1 sangat penting diperhatikan (Ludji, 2009, p. 73-74).

Jika diperhatikan dari akar katanya, hukum dalam perikop ini berbentuk orang kedua tunggal. Ini dapat dilihat pada ayat ke-2 dan ke-7. Jadi, maksudnya bahwa bagian ini bertindak sebagai kerangka hukum yang lebih tua (Mayes, 1985, p. 285). Hamilton menambahkan penjelasannya bahwa dalam kasus dua hukum pertama, ada beberapa kosakata umum untuk mengikat keduanya. "Kamu harus mempersiapkan jalan dan membaginya menjadi tiga bagian wilayah ( $\left.g^{e} b u l\right)$ dari tanah" (19:3), dan "kamu tidak akan (kembali) memindahkan batas tanah tetanggamu ( $g^{e} b u l$ ), yang telah disiapkan oleh para lelaki tua dalam mempersiapkan jalan-jalan. Istilah Ibrani yang dipakai di sini untuk menyatakan daerah yang sudah dikhususkan itu adalah לובְּג (baca: gebul).

Berdasarkan pandangan peneliti sendiri, kata ini jika diartikan secara harfiah berarti daerah perbatasan. Perbatasan adalah garis yang memisahkan jarak geografis. Istilah "batas" untuk menandai pemisahan antara negara-negara, tetapi juga mencatat perbedaan antara kota-kota di negara yang sama, kabupaten dan bahkan halaman belakang dari daerah perbatasan tersebut. Maka dari itu dikatakan, "Engkau harus mengkhususkan tiga kota ... supaya setiap pembunuh dapat melarikan diri ke sana" (UI. 19:2-3). Wycliffe menjelaskan bahwa:

Negeri yang terletak di bagian barat Sungai Yordan adalah wilayah yang dimaksudkan, sebab sebagaimana dikemukakan pada bagian penutup dari bagian pendahuluan historis (4:41-43), Musa telah menunjuk tiga kota perlindungan di sebelah timur Sungai Yordan. Peranan Yosua di dalam melaksanakan tugas pendirian tiga kota perlindungan ini merupakan tanda kesatuan fungsional dan dinasti di antara Yosua dengan Musa (bdg. Yos. 20) (Pfeiffer \& Harrison, 2004, p. 499).

Lebih jelas lagi mengenai kota tersebut dijelaskan oleh Craigie dalam bukunya sebagai berikut: Anda harus menyisihkan tiga kota berarti totalnya menjadi enam, termasuk ke timur sungai Yordan. Kemudian untuk kalimat di tengah tanah Anda berarti bahwa kota-kota akan dialokasikan secara geografis atau regional, namun tidak secara khusus terkait dengan wilayah kesukuan. Tujuan dari distribusi ini adalah untuk menyediakan tempat-tempat perlindungan dalam akses mudah ke semua wilayah tanah Israel di masa depan. Untuk mengalokasikan satu kota per suku mungkin telah mengalahkan tujuan kota-kota itu, dengan membuat undang-undang tersebut terkait dengan pembunuhan massal dan pembunuhan soal keadilan dan pembalasan kesukuan (Craigie, 1976, p. 265).

Dari pemaparan di atas, peneliti mengambil pandangan dari Harlow untuk menyederhanakan penjelasan tersebut sekaligus menyimpulkannya. Musa telah menamai tiga kota di pantai barat sungai Yordan yang bisa dilalui orang untuk menyelamatkan nyawa mereka. Sekarang dia mengingatkan Israel lagi bahwa mereka harus memberi tiga kota untuk tujuan ini di Tanah Perjanjian. Mereka harus membagi tanah menjadi tiga bagian dengan salah satu kota ini di setiap bagiannya. Mereka juga harus membangun jalan sehingga orang yang membunuh seseorang secara tidak sengaja bisa bertemu dengan salah satu kota ini dan menyelamatkan dirinya dari musuh-musuhnya. Seorang pria mungkin menggunakan kapaknya untuk memotong kayu. Kepala kapak mungkin akan terlepas dan terkena orang lain dan membunuhnya meski pemilik 
kapak itu tidak membencinya dan tidak berusaha menyakitinya. Tetap saja saudara laki-laki yang meninggal itu mungkin mengira telah melakukannya dengan sengaja dan ingin membunuhnya. Namun perlu diperhatikan bahwa seorang pria tidak bisa lari ke salah satu kota ini untuk menyelamatkan dirinya sendiri jika dia benarbenar merencanakan untuk membunuh orang lain (Harlow, 1986, p. 112).

Jika memerhatikan hal tersebut dengan saksama, dapat disimpulkan bahwa "kota-kota perlindungan" ini hampir mirip dengan kasus penahanan kota dalam hukum pidana di Indonesia sebagaimana yang diatur dalam Pasal 22 ayat (1) KUHAP mengenai jenis penahanan. Dalam peraturan tersebut, ada tiga jenis penahanan yaitu penahanan negara, penahanan rumah dan penahanan kota. Penahanan kota ini dilaksanakan di sebuah kota tempat tinggal atau tempat kediaman dari tersangka pelaku tindakan kriminal dengan syarat bahwa tersangka wajib melaporkan diri pada waktu tertentu. Jika tersangka akan keluar dari kota tersebut, harus mendapatkan izin dari pejabat yang menahan. (Kusumaatmaja, 2015, p. 13).

Menurut peneliti, perbedaannya hanya terletak pada motivasi dalam melakukan tindakan kriminal. Dalam "kota-kota perlindungan" yang dibahas pada teks Ulangan 19:1-13, pelaku pembunuhan mendapat perlindungan karena motivasi pembunuhan yang dilakukannya secara tidak sengaja. Sedangkan kasus penahanan kota di Pasal 21 ayat (1) KUHAP memang tersangka melakukan tindakan kriminal dengan motif kesengajaan hanya saja ada kewenangan dari pejabat yang memberikan beberapa pertimbangan mengenai pengalihan tahanan dari tahanan negara menjadi tahanan kota atau bahkan menjadi tahanan rumah. Jadi kesamaannya terletak pada lokasi khusus yang diberikan kepada masingmasing tersangka yang membuat tindakan kriminal.

Selanjutnya mengenai alat yang dipa- kai, F. C. Cook menjelaskan bahwa kapak tersebut terbuat dari besi. Kapak besi tersebut biasanya dipakai untuk peralatan (Cook, 1959, p. 308). Sedangkan mengenai prosedur yang sudah dikemukakan di atas mengenai tiga kota perlindungan ini oleh $\mathrm{R}$. E. Harlow nampaknya hal tersebut senada dengan pendapat Craigie yang menjelaskan bahwa pada ayat berikutnya yaitu ayat 5, fungsi kota perlindungan dalam kaitannya dengan kejahatan pembunuhan dijelaskan. Manslayer dapat didefinisikan sebagai orang yang membunuh orang lain secara tidak sengaja, tanpa maksud dan tanpa ada perasaan benci pada orang tersebut. Contoh dasar dan sederhana terdapat pada ayat 5 : dua orang pergi ke hutan untuk memotong kayu dan satu lagi terbunuh akibat kecelakaan karena salah kapak temannya. Orang yang bertanggung jawab atas kematian akibat kecelakaan semacam ini dapat menemukan tempat berlindung di kota terdekat dari tiga kota perlindungan tersebut (Craigie, 1976, p. 266).

Selanjutnya yang merupakan tugas dari sanak keluarga penebus adalah sebagai "penuntut tebusan darah" (Kej. 4:10). Menurut Wycliffe tugas ini harus dilaksanakan atas dasar keadilan. Sang "penuntut tebusan darah" tidak boleh bertindak atas dasar nafsu kejahatan untuk membalaskan dendamnya tersebut. Untuk itu, tugas ini sebenarnya sudah dibatasi secara bijaksana dalam sistem pemerintahan Israel yang baru sehingga lebih terpusat pada ketentuan perlindungan hukum yang berkaitan dengan mezbah (bdg. Kej. 4:15; Kel. 21:14b) (Pfeiffer \& Harrison, 2004, p. 500).

Penjelasan yang sama datang dari Mayes dalam bukunya. la mengatakan bahwa penuntut darah dalam teks Ibrani adalah gōēl haddām. Ini biasanya diambil untuk merujuk kepada keluarga terdekat dari orang terbunuh yang memiliki kewajiban membalaskan dendamnya dengan membunuh orang yang bertanggung jawab. Oleh karena itu, situasinya dipahami sebagai 
salah satu yang melibatkan kebiasaan penunggakan darah yang tersebar luas, di mana individu-individu di dalam kelompok kekerabatan bertanggung jawab atas kehidupan satu sama lain; Jika seseorang terbunuh maka anggota kelompok kekerabatannya harus membalas kematiannya atas pembunuh tersebut atau anggota kelompok kekerabatan pembunuh lainnya (Mayes, 1985, p. 286).

Craigie menjelaskan bahwa penuntut darah (gō'ē/ haddām)—dalam pembahasan ini-masih harus diartikan lebih dalam lagi sebab arti sebenarnya dari ungkapan ini cukup menjadi bahan perdebatan yang lumayan banyak. Secara tradisional, telah diambil kesepakatan yaitu untuk merujuk pada saudara laki-laki terdekat dari almarhum, yang atasnya bertanggung jawab untuk membalaskan dendam darah orang yang telah meninggal tersebut. Namun barubaru ini, pengertian tersebut telah ditafsirkan sebagai perwakilan para penatua kota tempat kematian terjadi. Oleh karena itu, dia adalah seorang pejabat (pelindung darah). Kota pengungsian bukan sekadar tempat yang aman, tapi tempat di mana penyewanya membuat penebusan bagi orangorang yang meninggal di mana dia bersalah. Jika kematian itu dipastikan akan menjadi pembunuhan, maka pelakunya akan dieksekusi (Craigie, 1976, p. 266).

la menambahkan bahwa masalah yang dibicarakan dalam ayat 6 ini bahwa penuntut darah dapat dihabisi dengan kemarahan dan membunuh orang yang melarikan diri. Sementara tindakan semacam itu tampaknya diizinkan secara berlebihan, ada bahaya ketidakadilan yang dilakukan jika buronan itu sebenarnya adalah seorang manslayer (dan karena itu tidak layak menerima hukuman mati) daripada seorang murderer. Maka dari itu, untuk alasanalasan tersebut, kota perlindungan harus dikhususkan (ayat 7) (Craigie, 1976, p. 266).

Selanjutnya Mayes kembali memberi pendapatnya mengenai ayat 8-10. la mengatakan bahwa ketiga ayat ini berbicara mengenai tanah dari kota perlindungan itu diberikan kepada para ayah dari jauh yang dijanjikan kepada mereka, hanya ditemukan pada akhir 1:8; 11:9; 21; 30:20. Jadi jika seseorang hendak memiliki kuasa atas kepemilikan seluruh tanah maka dibutuhkan sebuah kondisi ketaatan kepada hukum yang sudah Tuhan berikan (Mayes, 1985, p. 287).

Lebih jelas lagi mengenai ayat 8-10 dapat dilihat dari pandangan Craigie (1976) bahwa secara umum dapat diartikan penyediaan dilakukan untuk penambahan tiga kota perlindungan lainnya (total menjadi sembilan) terjadi jika sebagian wilayah yang lebih besar harus diduduki oleh Israel daripada yang dipertimbangkan dalam ay. 17. Ketentuan semacam itu penting karena sebagian dari prinsip yang mendasari penunjukkan kota pengungsian adalah kemudahan aksesibilitas, dan jika ada peningkatan besar dalam kepemilikan tanah, tiga kota pertama yang disisihkan akan jauh dari penduduk wilayah baru (Craigie, 1976, p. 267).

Dan jika Tuhan, Allahmu, memperluas daerahmu, tampaknya membayangkan bagian tanah yang terbentang di sebelah Barat Sungai Yordan, kata-kata ini menunjukkan bahwa konsep yang jauh lebih besar dari tanah perjanjian yang telah disebutkan di dalam 1:8 dan 11:23-24. Karena semua wilayah ini (dari perbatasan Mesir sampai Efrat) tidak pernah sepenuhnya dimiliki oleh orang Israel, ketentuan yang disebutkan dalam ayat-ayat ini tampaknya tidak diberlakukan pada saat apa pun selama sejarah Israel. Kondisi (ayat 9a) di mana perolehan wilayah yang lebih luas ini bersifat kontingen sangat mirip dengan yang disebutkan dalam 11:22. Kata-kata itu merupakan pengingat lain tentang penyajian hukum dalam Kitab Ulangan. Ketentuan tambahan untuk kota pengungsian lebih jauh ini memiliki tujuan yang sama seperti pada ayat 1-7, yaitu penghindaran pertumpahan darah yang tidak bersalah, dengan tanggung jawabnya, di Israel (ayat 
10) (Craigie, 1976, p. 267-268).

Selanjutnya mengenai penghindaran pertumpahan darah yang tidak bersalah, kembali Mayes memberi penjelasannya bahwa meskipun tidak disebutkan bahwa penumpahan darah yang tidak bersalah akan menyebabkan hilangnya tanah, konteks umum di mana peringatan untuk tidak menumpahkan darah yang tidak bersalah adalah kepemilikan tanah. Hubungan ini dapat disejajarkan dengan mengacu pada Kejadian 4 di mana penumpahan darah oleh Kain terhadap Habel menyebabkan hukuman Kain menjadi pengembara dan pelarian. Petunjuk pertumpahan darah: kata yang sama, dāmîm, berarti pertumpahan darah dan juga rasa bersalah bagi yang menumpahkan darah membawa serta hal itu. Untuk yang terakhir, lihat juga Kel. 22: 2; 2 Sam. 21:1; Mzm. 51:14 (Mayes, 1985, p. 287).

Kemudian tiga ayat terakhir dari Ulangan 19 ini merupakan penyebab dari hukuman yang harus diterima mengenai seseorang yang diserahkan kepada penuntut tebusan darah. Craigie memberikan penjelasannya bahwa berdasarkan ayat-ayat ini dapat dilihat aturan tentang penyalahgunaan kota-kota perlindungan. Kejahatan yang dijelaskan dalam ayat 11 adalah pembunuhan yang memang disengaja, bukan pembunuhan yang tidak disengaja atau karena kecelakaan. Pembunuhnya mungkin masih melarikan diri ke kota-kota perlindungan, tapi perlindungan yang mereka tawarkan tidak mencakup kejahatan yang dia lakukan (Craigie, 1976, p. 268).

Sedangkan Mayes memberikan penjelasan berbeda mengenai ayat ini. la mengatakan bahwa ayat 11 sesuai dengan ayat 4. Dalam memiliki formulasi impersonal dan bersikap santai. Mereka adalah lawan dari ay. 4, menjelaskan kasus pembunuhan yang disengaja sehubungan dengan kotakota tempat perlindungan dan mungkin merupakan bagian dari hukum pradeuteronomis (Mayes, 1985, p. 288).

Tua-tua kotanya (ayat 12), yaitu kota di mana penjahat hidup dan mungkin di mana kejahatan itu dilakukan. Para tua-tua ini, yang merupakan penjaga hukum di kota, menuntut penyerahan tawanan. Mereka kemudian akan menyerahkannya ke dalam kuasa (maksudnya "tangan") dari penuntut darah. Jika interpretasi yang disarankan dalam komentar tentang ayat 6 adalah benar, maka penuntut darah akan bertindak sebagai jaksa penuntut dan hadir. Buktinya melawan terdakwa di depan pengadilan (sesepuh) di kotanya sendiri. Saat memastikan keyakinan, pembalas darah kemudian bertanggung jawab atas eksekusi tersebut, bersama dengan anggota masyarakat lainnya (lihat 13:9). Janganlah engkau merasa sayang kepadanya-lihat juga 7:16. Alasan tindakan tegas adalah menghilangkan noda dari tanah yang diakibatkan oleh penumpahan darah yang tidak bersalah. Karena Tuhan diyakini tinggal di tanah bersama bangsa-Nya, maka tanah tersebut tidak akan menjadi najis (lihat Bil 35:34) (Craigie, 1976, p. 268).

Mengenai para tua-tua kota, tafsiran Wycliffe berpendapat sebagai berikut.

Para pejabat lokal ini memiliki tanggung jawab atas tertumpahnya darah orang yang tidak bersalah di sekeliling mereka (lihat 21:3 dst.), karena itu mereka diberi tugas memenuhi jeritan darah itu meminta keadilan (bdg. ay. 13), tetapi tanpa mencabut hak zaman dulu dari seorang penuntut balas (12b). Pengadilan itu sendiri harus dilaksanakan di hadapan "rapat umat" (Bil. 35:12, 24), maksudnya secara terbuka di hadapan umum, namun apakah langsung wilayah terjadinya pembunuhan ataukah di dalam kota perlindungan tidak dijelaskan. Yosua 20:4 (bdg. ay. 6) menyebutkan sebuah pengadilan, setidaktidaknya pengadilan pembukaan, yang harus diadakan di kota perlindungan (Pfeiffer dan Harrison, 2004, p. 500).

Artinya dapat diketahui bahwa para tua-tua kota (קוt baca: $\left.Z^{1} q e ̂ n\right)$ tersebut 
merupakan orang yang sudah dituakan dalam kota tersebut atau dianggap sesepuh yang diberi tugas untuk menegakkan hukum di kota tersebut dengan cara menyerahkan seorang pembunuh (murderer) kepada penuntut tebusan darah, supaya ia mati dibunuh. Mayes pun ikut menambahkan bahwa, "This is not the exercise of blood revenge, but judicial execution for murder, carried out by the community through its representative, the gō'ēl haddām" (Mayes, 1985 , p. 288). Artinya ialah ini bukan sebuah pembalasan dendam, tapi eksekusi yudisial atas pembunuhan yang dilakukan oleh masyarakat melalui perwakilannya. Dari penjelasannya dapat dilihat bahwa inilah kesimpulan deuteronomis terhadap hukum tentang "kota-kota perlindungan," dengan menggunakan ungkapan yang telah muncul di 13:5, 8. Klausa motif sehingga mungkin sesuai dengan Anda mungkin merupakan suplemen deuteronomis yang terlambat untuk hal ini (Mayes, 1985, p. 288).

Jadi berdasarkan penjelasan di atas, Harlow menyimpulkan bahwa Tuhan akan memberikan seseorang lebih banyak tanah jika mereka menaati-Nya dan mereka harus memberi tiga kota lagi. Tuhan ingin memastikan bahwa tidak ada yang akan mati karena tidak sengaja membunuh seseorang. Namun seseorang bisa membunuh temannya karena dia membencinya dan kemudian melarikan diri ke salah satu kota ini. Para tua-tua di kota itu tidak boleh mengizinkannya tinggal di sana: mereka harus membawanya keluar kota dan membunuhnya (Harlow, 1986, p. 112).

Mengacu pada hal tersebut jika hal ini dikaitkan dengan hukum pidana di Indonesia, terdapat kemiripan antara konsep "kota-kota perlindungan" ini dengan Rutan (Rumah Tahanan Negara). Rumah Tahanan Negara adalah sebuah tempat di mana orang yang diduga melakukan kejahatan ditempatkan di situ sebelum dinyatakan bersalah, artinya sebelum ada keputusan yang berkekuatan hukum tetap untuk mereka. Hal ini diatur dalam Pasal 1 angka
2 Peraturan Pemerintah RI Nomor 27 Tahun 1983 tentang Pelaksanaan Kitab UndangUndang Hukum Acara Pidana (PP No. 27 Th. 1983), yaitu "Rutan adalah tempat tersangka atau terdakwa ditahan selama proses penyidikan, penuntutan dan pemeriksaan di sidang pengadilan" (Puspitasari, 2018, p. 36). Namun yang menjadi perbedaan adalah penggagas dari aturan tersebut. Jika peraturan mengenai "Rutan" digagas oleh peraturan pemerintah, berbeda dengan "kota-kota perlindungan." Gagasan kota perlindungan dipikirkan dan diberikan langsung oleh TUHAN Allah yang sungguh memerhatikan ciptaan-Nya.

Dari perikop ini kita dapat mempelajari dua sifat TUHAN yang memengaruhi perkara ini. Di satu sisi, la menunjukkan keadilan-Nya lewat perintah-Nya bahwa setiap orang yang bersalah wajib menanggung hukuman atas kesalahannya. Tetapi di sisi lain, la juga menunjukkan kemurahanNya dengan membebaskan orang yang tidak bersalah dan mencegah kekeliruan orang lain untuk menghukum orang yang tidak bersalah. Kiranya ini menjadi pegangan bagi setiap orang percaya bahwa TUHAN adalah tempat perlindungan yang sejati bagi umat-Nya yang tidak bersalah.

\section{Relevansi Ulangan 19:1-13 Bagi Gereja Masa Kini}

Dari penjelasan yang sudah dipaparkan di atas, tentunya ada beberapa prinsipprinsip yang masih relevan untuk diterapkan di zaman sekarang. Walaupun kota-kota perlindungan tidak lazim dikenal di zaman modern ini dan juga kurang mendapat perhatian untuk dikhotbahkan kepada para jemaat, namun masih ada beberapa kebenaran yang dapat direlevansikan bagi gereja masa kini. Berikut penjelasan mengenai relevansi Ulangan 19:1-13 bagi gereja masa kini.

\section{Relevansi Teologis}

Adapun relevansi teologis dari "kotakota perlindungan" dalam teks Ulangan 
19:1-13 menghasilkan beberapa kebenaran yakni Allah yang Maha Berdaulat, Allah yang Maha Pemurah dan Allah yang Maha Adil. Berikut penjelasannya.

\section{Allah yang Maha Berdaulat (ayat 4)}

Clark H. Pinnock mengungkapkan bahwa Kedaulatan Allah adalah tema sentral dari kekristenan (Pinnock, 1996, p. 15). Dari pembahasan teks Ulangan 19:1-13 dapat diketahui bahwa salah satu sifat Allah yang sangat menonjol dalam teks ini ialah Allah yang Maha Berdaulat. Di mana dapat diperhatikan pada ayat 4 yang berbunyi: "Inilah ketentuan yang diberikan TUHAN, Allahmu, untuk dimiliki olehmu, supaya setiap pembunuh dapat melarikan diri ke sana [kota-kota perlindungan]." Allah dari awalnya sudah menentukan bahwa perlindungan berhak juga diberikan kepada orang-orang yang tidak sengaja melakukan kesalahan. Tentu saja ini merupakan salah satu bukti bahwa la sungguh berdaulat atas kematian dan kehidupan makhluk ciptaanNya.

Hal ini mungkin saja tidak terpikirkan oleh setiap manusia pada umumnya namun pengawasan Allah luar biasa. Tindakan ini menggambarkan bahwa Allah sungguh berdaulat dan Maha Kuasa sekaligus Maha Tahu, begitu juga Tuhan yang transenden, diri-Nya eksis dan melampaui ruang dan waktu. Pengawasan-Nya mencakup makhluk yang perasaannya peka sampai bendabenda mati sekalipun (Carson, 2010, p. 5253). Oleh sebab itu, biarlah setiap orang percaya dapat mengenal dan memberikan respons pengagungan atas salah satu sifat Allah yang dibahas dalam perikop ini, di mana la adalah Allah yang Berdaulat dan bukan hanya itu saja, la juga adalah Allah yang sungguh mengawasi dan mengasihi seluruh makhluk ciptaan-Nya.

\section{Allah yang Maha Pemurah (ayat 6-7)}

Selain berdaulat, dari teks Ulangan 19:1-13 setiap pembaca dapat belajar bahwa salah satu sifat Allah yang cukup menonjol adalah la merupakan Allah yang Maha Pemurah. Bagaimana tidak, dalam ayat yang ke 6-7, Allah merancangkan dan berinisiatif untuk memberi perintah kepada umat-Nya untuk mengkhususkan tiga kota kepada para pembunuh yang tidak sengaja melakukan tindakan tersebut. Ini yang merupakan salah satu contoh sifat Allah yang perlu direnungkan oleh orang percaya.

Sebagai Allah yang Maha Pemurah, la dapat diumpamakan sebagai suatu energi yang tidak terbatas dan yang tidak ada habisnya, yang terdapat di dalam tabiat Allah. Hal ini bukan hanya terdapat dalam Perjanjian Baru saja tetapi juga dalam Perjanjian Lama. Bahkan Perjanjian Lama membahas belas kasihan Allah empat kali lebih banyak daripada Perjanjian Baru (Tozer, 2006, p. 127). Hal ini cukup penting untuk dipahami oleh setiap orang percaya pada masa kini yang terkadang menganggap bahwa Allah Perjanjian Lama cenderung penuh dengan murka dan penghakiman sedangkan Allah Perjanjian Baru adalah Allah yang berbelas kasihan dan penuh dengan kemurahan.

Yang harus dipahami bahwa Allah kita adalah Allah yang maha adil sekaligus Allah yang maha pemurah. Tetapi keselamatan yang diberikan kepada setiap manusia sama sekali tidak murahan. la menebus manusia dengan darah yang mahal, yaitu darah Kristus (1 Ptr. 1:19). Maka dari itu benarlah pernyataan dari Rudolf Otto mengenai "Allah Sang Misteri" yang menggambarkan dua sifat Allah yakni menakutkan (karena murkaNya) namun juga menarik (karena kemurahan-Nya). Tetapi yang harus menjadi fokus dari setiap gereja untuk merefleksikan sifat Allah yaitu kemurahan-Nya sebab Otto berpendapat bahwa "kemarahan Allah terhisap di dalam "kemurahan-Nya" (Triasmoroadi, 2018, p. 47).

Oleh sebab itu, bukti konkret dari keadilan dan kemurahan Allah dinyatakan dan dipertemukan melalui pengorbanan Yesus Kristus di atas kayu salib. Konstruksi gambar Allah yang pemurah kiranya dapat 
memberikan kedamaian sehingga banyak orang yang mendekatkan diri terhadap Allah.

\section{Allah yang Maha Adil (ayat 11-13)}

Para penulis Alkitab sering menggambarkan Allah sebagai hakim kerajaan yang membawa keadilan bagi seluruh ciptaan-Nya yang jatuh ke dalam dosa (Beck, 2017, p. 33). Begitu juga dalam teks yang sedang dibahas. Ulangan 19:1-13 ditutup dengan firman Allah yang sangat menggambarkan sifat kemahaadilan-Nya. Jika diperhatikan secara saksama dalam ayat 11-13, Allah sedang menyuruh para tua-tua kotanya (baca: kota-kota perlindungan) untuk mengambil pembalas dendam (pembunuh yang membalas dendam atas kematian rekannya yang tidak sengaja terbunuh) untuk dibunuh. Bahkan pada ayat yang ke-13 dikatakan bahwa: "Janganlah engkau merasa sayang kepadanya. Demikianlah harus kau hapuskan darah orang yang tidak bersalah dari antara orang Israel, supaya baik keadaanmu."

Dari kisah ini para pembaca dapat belajar bahwa keadilan Allah adalah sebuah keadaan yang mutlak. Mutlak dalam hal keadilan Allah sejalan dengan kesucianNya. Oleh sebab itu J. Wesley Brill berpendapat bahwa kesucian Allah tampak dalam tabiat Allah namun kebenaran dan keadilan Allah tampak dalam interaksinya dengan manusia. Kebenaran Allah yang memprakarsai hukum-hukum dan keadilan Allah yang melaksanakan hukum-hukum tersebut yakni dengan menghukum yang bersalah dan membenarkan yang bertindak sesuai dengan kebenaran (Brill, 2015, p. 84).

Dari hal ini dapat ditarik kesimpulan bahwa Allah tidak pernah berubah dari tujuan-Nya yang semula. Boice menuangkan pikirannya bahwa tujuan-tujuan Allah untuk orang fasik tidak akan berubah. Tujuan-Nya adalah menghakimi mereka, dan itulah yang akan la lakukan. Allah "tidaklah sekali-kali membebaskan orang yang bersalah" (Kel. 34:7) (Boice, 2015, p.
157).

Melalui penjelasan ini, sudah seharusnya menjadi peringatan bagi setiap orang percaya untuk mengingatkan kepada sesama manusia secara khusus yang belum percaya kepada Yesus sebagai Tuhan dan Juruselamat mereka untuk segera berbalik dan bertobat sebab penghukuman yang kekal pasti ada di luar Yesus Kristus.

\section{Relevansi Praktis}

Selain relevansi secara teologis, dari analisis teks Ulangan 19:1-13 juga dihasilkan beberapa kebenaran yang dapat direlevansikan secara praktis dalam kehidupan orang percaya masa kini. Adapun relevansi praktis dari kajian biblika terhadap Ulangan 19:1-13 adalah setia melakukan perintah Allah, percaya bahwa Yesuslah pelunas hutang darah yang sejati, dan hidup dalam kekudusan. Berikut penjelasannya.

\section{Setia Melakukan Perintah Allah (ayat 4)}

Telah dijelaskan dalam perikop ini, Ulangan 19 berbicara mengenai perintah Allah kepada umat-Nya untuk mendirikan tiga kota perlindungan bagi para pembunuh yang tidak sengaja membunuh rekannya untuk dapat melarikan diri ke kota tersebut. Bahkan jika umat-Nya setia melakukan perintah Allah, di ayat yang ke-9 Allah mengatakan kepada mereka bahwa haruslah menambah tiga kota lagi kepada yang tiga itu. Ini berarti bahwa total ada enam kota perlindungan. Hal ini tentu saja mengajarkan kepada para pembaca bahwa respons yang benar ketika Allah berbicara ialah setia melakukan perintah-Nya.

Ketika Allah berdaulat atas segala sesuatu, tidak ada seorang pun yang dapat menghalangi bahkan menggagalkan rencana Allah. Untuk itu, respons yang benar saat menyadari bahwa Allah mampu dan sanggup untuk bertindak dalam menggerakkan pikiran dan hati manusia untuk mencapai kehendak-Nya adalah dengan berlaku setia. Setia di sini tentu harus ditunjukkan dengan perbuatan yang sejalan. Salah satunya ialah 
percaya. Respons pertama setiap kita adalah percaya. Kita perlu setia dan percaya bahwa tidak ada seorang pun dapat membahayakan atau mengancam kehidupan manusia di luar kehendak Allah yang berdaulat (Bridges, 2010a, p. 45). Sekali lagi, yang diperlukan hanyalah sikap hati untuk senantiasa setia melakukan apapun yang diperintahkan oleh Allah. "Sebab TUHAN, Allahmu, berjanji di akhir kitab ini bahwa la akan mengangkat engkau di atas segala bangsa di bumi" (UI. 28:1).

\section{Percaya bahwa Yesuslah Pelunas Hutang Darah yang Sejati (ayat 6-7)}

Ulangan 19:6-7 jelas berbicara mengenai awasan agar jangan ada penuntut tebusan darah. Telah dijelaskan secara gamblang di halaman 10 mengenai penuntut darah. Darah sebenarnya memiliki pengaruh yang sangat kuat dengan pengampunan baik dalam Perjanjian Lama maupun Perjanjian Baru. Hal ini dapat dilihat dari awal mula kejatuhan manusia ke dalam dosa di taman Eden. Darah adalah media untuk menebus kesalahan manusia walaupun memang tidak disebutkan secara teologis dalam Kejadian 3:21. Namun dapat diketahui bahwa saat itu TUHAN Allah membuat pakaian dari kulit binatang untuk manusia. Hal itu berarti ada penumpahan darah yang terjadi ketika manusia jatuh ke dalam dosa.

Begitu juga dalam kitab-kitab Taurat, darah terus dipakai sebagai media dan simbol secara khusus untuk penebusan. Hal ini dapat dilihat dari cerita darah anak domba yang dibubuhkan pada kedua tiang pintu rumah umat Israel ketika tulah kesepuluh yakni kematian anak sulung sedang melanda Firaun dan tanah Mesir (Kel. 11-12). Bahkan hal tentang darah ini berulang dalam teks Ulangan 19:6-7. Bukan hanya sampai di situ saja, ketika berbicara mengenai hubungan yang ada antara Perjanjian Lama dan Perjanjian Baru, semuanya akan sampai pada titik di mana Yesus Kristus datang untuk menggenapi ramalan Mesias yang akan datang dalam Perjanjian Lama (Kaisler, 2013, p. 335-337).

Yesus datang untuk mengorbankan diri-Nya di kayu salib sebagai pelunas hutang darah yang sejati. Sebab dalam Perjanjian Baru juga berbunyi demikian: "Dan hampir segala sesuatu disucikan menurut hukum Taurat dengan darah, dan tanpa penumpahan darah tidak ada pengampunan" (Ibr. 9:22). Itu sebabnya "demikian pula Kristus hanya satu kali saja mengorbankan diri-Nya untuk menanggung dosa banyak orang. Sesudah itu la akan menyatakan diri-Nya sekali lagi tanpa menanggung dosa untuk menganugerahkan keselamatan kepada mereka, yang menantikan Dia" (Ibrani 9:28).

\section{Hidup Dalam Kekudusan (ayat 11-13)}

Salah satu tanggung jawab yang orang percaya perlu laksanakan dalam kehidupan masa kini adalah hidup dalam kekudusan. Jika memerhatikan ayat 11-13 dari Ulangan 19 maka akan didapati beberapa langkah tuntutan Allah bagi umatNya ketika berlaku tidak kudus. Langkahlangkah ini bisa dikatakan formasi lengkap dari tindakan dosa yang awalnya kecil namun lama kelamaan akan semakin besar. Dosa pertama yang dibahas ialah membenci sesamanya manusia. Setelah itu berkembang ke langkah selanjutnya yaitu bersembunyi untuk menantikan dia, lalu bangun untuk menyerang atau memukul dia, sehingga mati, kemudian melarikan diri. Hal ini tentunya merupakan contoh hidup manusia yang berada di luar kekudusan.

Sebagai orang percaya yang memiliki Allah yang Maha Kudus, seharusnya kita merespons kekudusan yang sudah diberikan oleh Allah. Itulah sebabnya Tozer berpendapat bahwa Allah mengaruniakan kekudusan-Nya dengan jalan memberikannya melalui Darah Anak Domba maka la menuntut agar umat-Nya senantiasa hidup dalam kekudusan tersebut. Pada awalnya kepada umat Israel, lalu kemudian kepada seluruh umat-Nya dengan berkata: "Kudus- 
lah kamu sebab Aku kudus" (1 Ptr. 1:16) (Tozer, 2006, p. 150). Dari penjelasan ini, dapat diketahui bahwa kekudusan Allah seharusnya menjadi penghiburan dan jaminan bagi setiap orang percaya untuk hidup dalam kekudusan. (Webster, 2004, p. 249).

Pandangan ini senada dengan Jerry Bridges yang mengatakan bahwa Allah sungguh menuntut kekudusan yang sempurna dari semua ciptaan-Nya yang bermoral. Tidak ada pilihan lain. la tidak dapat menerima atau menyetujui satu bentuk kejahatan pun. Oleh karena Allah kudus, la tidak pernah dapat bertoleransi atau menganggap remeh dosa yang dilakukan oleh umat-Nya, sekecil apapun tampaknya (Bridges, 2010b, p. 25). Maka dari itu, sebagai orang percaya yang sudah ditebus oleh Darah Yesus yang mahal, berusahalah hidup damai dengan semua orang dan kejarlah kekudusan, sebab tanpa kekudusan kita tidak dapat melihat Allah (lbr. 12:14).

\section{KESIMPULAN}

Dengan mengacu kepada seluruh hasil analisis dan uraian mengenai "kotakota perlindungan" berdasarkan Ulangan 19:1-13 dan relevansinya bagi gereja masa kini, maka peneliti menyimpulkan, walaupun teks-teks dalam Perjanjian Lama kelihatannya tidak mudah dimaknai ke dalam situasi dan zaman modern ini, namun orang percaya perlu belajar teks Perjanjian Lama agar dapat menolong pembaca awam untuk melihat dan menemukan makna teologis dari teks-teks tersebut yang relevan atau masih bisa diterapkan ke dalam kehidupan masa kini.

Konsep dari "kota-kota perlindungan" sebenarnya memiliki kesamaan dengan hukum pidana di Indonesia, khususnya dalam KUHAP mengenai tahanan kota. Perbedaannya hanya terletak pada motivasi dalam melakukan tindakan kriminal. Dalam "kota-kota perlindungan" yang dibahas pada teks Ulangan 19:1-13, pelaku pembunuhan mendapat perlindungan dalam "kota-kota perlindungan" karena motivasi pembunuhan yang dilakukannya secara tidak sengaja. Sedangkan kasus penahanan kota di Pasal 21 ayat (1) KUHAP tersangka memang melakukan tindakan kriminal dengan motif kesengajaan. Hanya saja pejabat yang berwenang boleh memberikan beberapa pertimbangan mengenai pengalihan tahanan dari tahanan negara menjadi tahanan kota atau bahkan menjadi tahanan rumah. Namun kesamaan yang mencolok dalam bagian ini terletak pada lokasi khusus yang diberikan kepada masing-masing tersangka.

Selain itu, kesamaan yang lain yang peneliti dapati yaitu dari peraturan pemerintah mengenai Rutan (Rumah Tahanan Negara). Jika rutan merupakan sebuah tempat sementara sebelum seseorang dinyatakan bersalah dan menerima putusan hukum, maka "kota-kota perlindungan" juga merupakan tempat yang dikhususkan oleh umat Israel untuk melindungi pembunuh yang tidak sengaja melakukan kasus pembunuhan. Peraturan tersebut diprakarsai langsung oleh TUHAN Allah untuk menghindari terjadinya pertumpahan darah orang yang tidak bersalah di negeri yang sudah diberikan TUHAN kepada umat-Nya dan hutang darah melekat kepada mereka (UI. 19:10).

Dari bagian ini dapat diketahui bahwa yang menjadi perbedaan adalah penggagas dari aturan tersebut. Jika peraturan mengenai "Rutan" digagas oleh peraturan pemerintah, "kota-kota perlindungan" digagaskan dan diprakarsai langsung oleh TUHAN Allah yang menunjukkan bahwa la sangat memerhatikan umat-Nya.

Kemudian melalui analisis Ulangan 19:1-13 peneliti berhasil menemukan beberapa relevansi baik dari segi teologis maupun praktis yang dapat diterapkan oleh gereja pada masa kini. Adapun relevansi dari analisis biblika terhadap teks Ulangan 19:1-13 menghasilkan beberapa kebenaran yaitu Allah kita adalah Allah yang Maha Berdaulat, di mana la berdaulat untuk 
mengawasi dan memelihara setiap ciptaanNya. Kemudian, la juga adalah Allah yang Maha Pemurah sekaligus Allah yang Maha Adil di mana keduanya ini ditunjukkan melalui pengorbanan Anak-Nya yang tunggal yaitu Yesus Kristus di kayu salib. Untuk itu, gereja perlu setia melakukan

\section{DAFTAR RUJUKAN}

Barker, P. (2014). Kitab Ulangan: Allah yang Menepati Janji-janji-Nya. Jawa Timur: Literatur Perkantas.

Beck, R. (2017). God The Judge and Human Justice. Journal of Law and Religion, 32(1), https://doi.org/10.1017/jlr.2017.11

Boice, J. M. (2015). Dasar-Dasar Iman Kristen: Sebuah Theologi yang Komprehensif dan Mudah Dibaca. Surabaya: Momentum.

Brake, A. (2019). Diktat Teologi Perjanjian Lama. Makassar: STFT Jaffray Makassar. Belum dipublikasikan.

Bridges, J. (2010a). Apakah Allah Benarbenar Memegang Kendali? Bandung: Pionir Jaya.

$$
\text { (2010b). Mengejar }
$$

Kekudusan. Bandung: Pionir Jaya.

Brill, J. W. (2015). Dasar yang Teguh. Bandung: Kalam Hidup.

Carson, D. A. (2010). Doktrin yang Sulit mengenai Kasih Allah. Surabaya: Momentum.

Cook, F. C. (1959). The Bible Commentary: Exodus-Ruth. Grand Rapids: Baker Book House.

Craigie, P. C. (1976). The Book of Deuteronomy. Grand Rapids: William B. Eerdmans Publishing Company.

Drew, C. J., Hardman, M. L., \& Hosp, J. L. (2017). Penelitian Pendidikan: Merancang dan Melaksanakan Penelitian pada Bidang Pendidikan. Jakarta: Indeks.

Hadad, E. (2017). "Unintentionally" (Numbers 35:11) and "Unwittingly" (Deuteronomy 19:4): Two Aspects of perintah Allah, percaya bahwa Yesus satusatunya pelunas hutang darah yang sejati dan hidup dalam kekudusan. Ketiga kebenaran ini adalah hal yang berkesinambungan dan seharusnya dilakukan oleh gereja pada masa kini dalam merespons keselamatan yang sudah diperoleh.

the Cities of Refuge. AJS Review, 41(1), 155-173. https://doi.org/10.1017/S03640094170 00071

Hamilton, V. P. (1982). Handbook on the Pentateuch. Michigan: Grand Rapids.

Harlow, R. E. (1986). Desert Journey: Studies in Numbers \& Deuteronomy. Canada: Everyday Publications Inc.

Kaisler, Jr., W. C. (2013). Teologi Perjanjian Lama. Malang: Gandum Mas.

Kusumaatmaja, A. M. I. (2015). Implementasi Hak-Hak Tahanan Di Rumah Tahanan Negara Kelas I Makassar. Skripsi S.H., Universitas Hasanuddin Makassar.

Lewis, E. (2014). Studi Biblika dan Teologis Surat 2 Petrus Pasal 3. Jurnal Jaffray, 12(2), 317-332. http://dx.doi.org/10.25278/jj71.v12i2.21

Ludji, B. (2009). Tafsiran Beberapa Teks Perjanjian Lama. Bandung: Bina Media Informasi.

Mattison, K. (2018). Contrasting Conceptions of Asylum in Deuteronomy 19 and Numbers 35. Vetus Testamentum 68(2), 232-251. https://doi.org/10.1163/1568533012341316

Mayes, A. D. H. (1981). The New Century Bible Commentary: Deuteronomy. Grand Rapids: Wm. B. Eerdmans Publ. Co., and London: Marshall, Morgan \& Scott Publ. LTD.

Mayes, P. L. (1998). Cities of Refuge. Calvary Baptist Theological Journal, 14(1), 1-25. https://biblicalstudies.org.uk/pdf/cbtj/14 -1_001.pdf 
Pfeiffer, C. F. \& Harrison, E. F. (eds.). (2004). The Wycliffe Bible Commentary. Malang: Gandum Mas.

Pinnock, C. H. (1996). God's Sovereignty In Today's World. Theology Today, 53(1), 15-21. https://doi.org/10.1177/004057369605 300103

Pratt, Jr., R. L. (2005). la Berikan Kita KisahNya: Panduan Bagi Siswa Alkitab Untuk Menafsirkan Narasi Perjanjian Lama. Surabaya: Momentum.

Puspitasari, C. A. (2018). Tanggung Jawab Pemerintah Dalam Pelanggaran Hak Narapidana Dan Tahanan Pada Lembaga Pemasyarakatan/Rumah Tahanan Negara. Jurnal Panorama Hukum, 3(1), 33-46. https://doi.org/10.21067/jph.v3i1.2342

Stackert, J. (2006). Why Does Deuteronomy Legislate Cities of Refuge? Asylum in the Covenant Collection (Exodus
21:12-14) and Deuteronomy (19:1-13). Journal of Biblical Literature, 125(1), 23-49.

https://www.jstor.org/stable/27638345

Sutanto, H. (2007). Hermeneutik: Prinsip dan Metode Penafsiran Alkitab. Malang: Literatur Saat.

Tozer, A. W. (2006). Mengenal yang Mahakudus. Bandung: Kalam Hidup.

Triasmoroadi, H. (2018). TEOLOGI KEM(U)(A)RAHAN ALLAH: Sebuah Upaya Mengkonstruksikan Teologi Kemurahan Allah. Gema Teologi 3(1), 39-52.https://journaltheo.ukdw.ac.id/index.php/gemateolog ika/article/view/318/255

Webster, J. (2004). The Holiness and Love of God. Scottish Journal of Theology, 57(3), 249-268. https://doi.org/10.1017/S00369306040 00250 